\title{
CHANGES IN FRAGMENTATION AND THE ECOLOGICAL STABILITY OF FLOODPLAIN FOREST GEOBIOCENOSIS IN THE RIVER MORAVA FLOODPLAIN OVER THE COURSE OF THE 20 ${ }^{\mathrm{TH}}$ CENTURY
}

\author{
(VRAPAČ NATIONAL NATURE RESERVE, LITOVELSKÉ POMORAVÍ, CZECH REPUBLIC)
}

\author{
IVO MACHAR
}

Department of Biology, Faculty of Education, Palacky University, Olomouc, Purkrabská 2, 77140 Olomouc, Czech Republic; Telephone: +420/58563 5183, e-mail: ivo.machar@upol.cz

Received: $4^{\text {th }}$ June 2008 , Accepted: $31^{\text {st }}$ October 2008

\begin{abstract}
The process of ecosystem fragmentation influences diversity and ecological stability in a significant way. This paper presents the results of analysis of changes in fragmentation and the ecological stability of the floodplain forest geobiocenosis in the Vrapač National Nature Reserve, a model area used for research into optimal forest reserve management methods in the Czech Republic (Simon, 2007). Using GIS methods, it was determined that fragmentation within this floodplain forest area decreased slightly between 1938 and 2006, and that the ecological stability of the landscape remains high. The results speak in favour of those theories advocating anthropogenic conditioning of floodplain forest ecosystems and show that even strongly anthropogenically modified geobiocenoses may show a high level of ecological stability, which is especially characteristic of the geobiocenoses of floodplain forests (Maděra, 2003).
\end{abstract}

Keywords: Fragmentation, diversity, ecological stability, geobiocenosis, floodplain forest, national nature reserve management

\section{INTRODUCTION}

The fragmentation of ecosystems in a landscape is one of the core themes of landscape ecology (Farina, 2007) and is considered an important problem for nature protection (Franklin et al., 2002; Primack et al., 2001; Thomson, 2006; Walker et al., 2006). Fahrig (2003) has reviewed the substantial literature that exists on this topic. The process of ecosystem fragmentation significantly influences ecological stability, which, in Míchal's (1994) view, is the inverse value of human labour input into an ecosystem aiming at its preservation at a desired state. The geobiocenoses of the floodplain forests of Central Europe within the floodplain landscape are distinguished by a dynamic ecological stability (Machar, 2001b). The dynamic essence of ecological stability in a floodplain landscape is articulated in the concept of the "dynamic fluvial seral series of floodplain biotopes" (Buček and Lacina, 1994).

The aim of this work is to assess the development of fragmentation and changes in the ecological stability of the floodplain forest geobiocenosis within the study area of the Vrapač National Nature Reserve (Litovelské Pomoraví Protected Landscape Area, Czech 
Republic), and to contribute to the understanding of anthropogenic influences that have formed the present state of the floodplain forest geobiocenosis, considered a biotope type important at the European level (Chytrý et al., 2001). This should contribute to drawing up a management plan for the reserve, which is one of the model study areas for the exploration of optimal management methods for forest reserves in the Czech Republic (Simon, 2007).

\section{METHODS}

\section{The study area}

The study area consists of the floodplain forest within the Litovelské Pomoraví Landscape Protected Area within the Vrapač National Nature Reserve and its immediate surroundings in the floodplain of the River Morava. The area is located in the eastern part of the Czech Republic (Fig. 1), $2 \mathrm{~km}$ west from the town of Litovel, at an altitude of 236 m.a.s.l. (or at quadrant 6,268 of the Central European mapping of flora and fauna) and at geographic coordinates $17^{\circ} 02^{\prime} \mathrm{E}, 49^{\circ} 42^{\prime} \mathrm{N}$. The basic biogeographic characteristics of the area and its biota stem from its geographic location within the Litovel Bioregion (see Culek, 1996). The floodplain forest geobiocenosis within the Vrapač National Nature Reserve consists of large complexes of mature forest growth, belonging to the higher orders of the geobiocene type group Ulmi-Fraxineta carpini, which in forestry typology belong to the elm-alder forest type of floodplain on alluvium (Machar, 2001a). In the biotope typology of Natura 2000 (Chytrý et al., 2001), it is termed alluvial hardwood forest of the lowland rivers biotope type. The Vrapač National Nature Reserve is situated in the first zone of nature protection in the Litovelské Pomoraví Protected Landscape Area (Fig. 2). For a more detailed description of the reserve and its biota, see Montágová (1999).

\section{Fig. 1: Location of the Vrapač National Nature Reserve study area in the Czech} Republic.

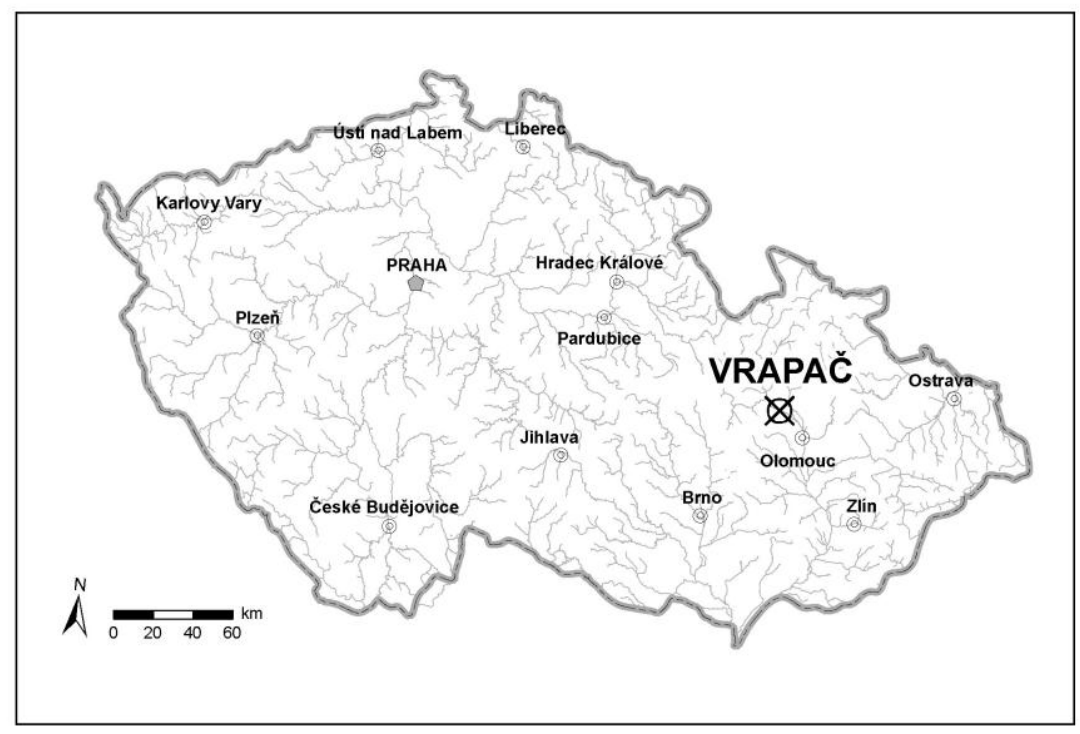




\section{Fig. 2: The Vrapač locality in the Litovelské Pomoraví Protected Landscape Area}

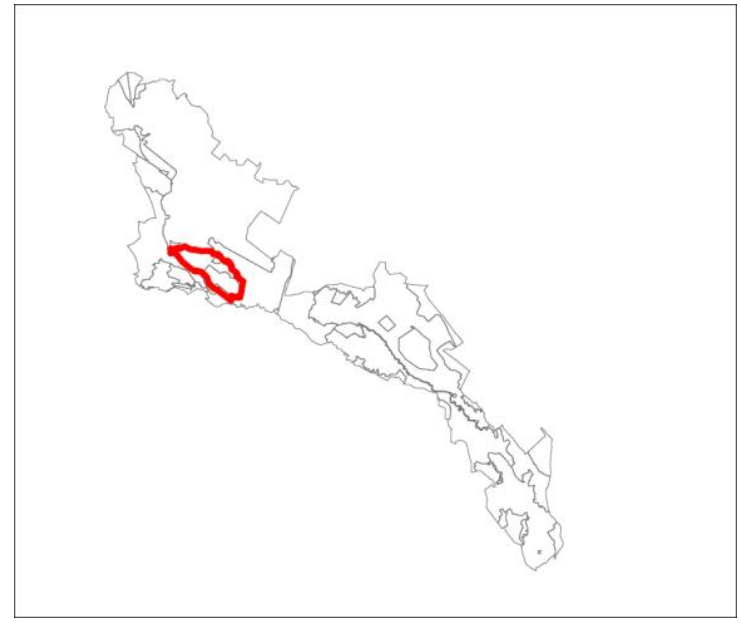

\section{Attributes analysed and data sources}

With the help of GIS methods, the following attributes related to landscape change were analysed for the years 1938, 1953, 1990 and 2006: the total area of individual types (categories) of land use (in ha) and its percentage representation, the number of patches and the total length of the patch edges (in $\mathrm{m}$ ), the relative length of the patch edges (in $\mathrm{m} / \mathrm{ha}$ ), the average size of patches (in ha), and the variability in patch size. The landscape heterogeneity index $(V)$ was calculated using the methodology of Mimra (1993):

$$
V=\frac{N}{\sqrt{A}} \cdot \frac{H}{H^{\prime}},
$$

\section{(1)}

where $\mathrm{N}$ is the total area of the elements within the mosaic, $\mathrm{A}$ is the value of the total area of the mosaic (elements and matrix), $\mathrm{H}$ is the actual type diversity of elements, and $\mathrm{H}^{\prime}$ the potential type diversity of elements. The calculation of conventional diversity indices was carried out using the classical equation for index diversity:

$H=-\sum_{i=1}^{j} p_{i .} \log p_{i}$,

(2)

where $\mathrm{pi}$ is the relative number of elements in the matrix to the $\mathrm{i}^{\text {th }}$ combination of the given characteristics and $\mathrm{j}$ is the total number of present combinations. Furthermore, the anthropogenic impact coefficient (Kaov) (Löw ed., 1995) was identified using the equation:

$$
K_{a o v}=\frac{I+I I+I I I+I V+V}{V I+V I I+V I I I+I X+X} .
$$

In this equation, $I-X$ are values of relative anthropogenic influence on vegetation. In order to analyse changes in the ecological stability of the study area, the degree of 
ecological stability of the forest stands was identified according to Buček and Lacina (1996). A six-point scale was used to evaluate the significance of the existing communities from the point of view of ecological stability: 0 - no significance, 1 - very little significance, 2 - little significance, 3 - medium significance, 4 - great significance, 5 extraordinary significance. The ecological stability coefficient $\left(\mathrm{K}_{\mathrm{ES}}\right)$ was determined in two ways, i.e. according to Míchal (1985):

$$
K_{E S}=\frac{S}{L} \text {, }
$$

(4)

where $\mathrm{S}$ is the total area of ecologically stable landscape structures and $\mathrm{L}$ is the total area of ecologically unstable landscape structures), and according to Miklós (1986):

$$
K_{E S}=\frac{p_{a} \cdot k_{p n}}{P},
$$

where $p_{a}$ is the area of land-use categories, $k_{p n}$ is the coefficient of the ecological importance of land-use categories, and $P$ is the range of study area. The $k_{p n}$ coefficient was altered by Lipský (2000) such that arable land has a value of 0.14 , meadows 0.62 , pastures 0.68 , gardens 0.68 , orchards 0.3 , forests and water bodies 1.0 , and others 0.1 .

Within the study area, 6 categories of land use were identified for the years 1938 to 2006: water (including areas of water such as the River Morava and its side channels, as well as permanently flooded and intermittent channels), non-stocked forest land (including meadows and roads), and four categories for floodplain forest geobiocenosis, i.e., clear-cut areas (non-stocked forest land resulting from clear-cutting), plantation (forest stands of 1 to 20 years of age), pole-stage stand (forest stands of 21 to 40 years of age), and stem wood (forest stands of 41 and more years of age). Analysis was carried out using aerial photographs of forest stand maps at the 1:10,000 scale from the archive of the Forest Management Institute, Brandýs nad Labem, for the years 1938, 1953, 1990 and 2006; and topographic maps at the 1:10,000 scale. The data were scanned as a raster display, digitized and subsequently analysed using the common statistical tools from the GIS environment (Topol programme, version 5.5.).

\section{RESULTS}

The development of coverage in the study area, according to the various land-use categories for the years 1938, 1953, 1990 and 2006, is shown in Figure 3. The figure clearly shows that the age of the forest stand has gradually increased between the years 1938 and 2006. In 2006, the dominant land-use area was "stem wood", i.e. mature stands of old floodplain forest. The total area of forest in the study area increased moderately (from 250 ha in 1938 to 285 ha in 2006), presumably caused by the gradual spontaneous expansion of the floodplain forest into the small enclaves formed by meadows. The structure of the landscape mosaic shows that the area tends toward unification of landscape structure and a gradual decrease in the fragmentation level of the floodplain forest geobiocenosis. Table 1 shows a strong decrease in the length of the edges dividing the floodplain forest from the non-stocked forest land (i.e. water areas, meadows) between the years 1938 and 2006. 
Table 1: Statistics of the landscape coverage in the study area

\begin{tabular}{|c|c|c|c|c|c|c|c|c|}
\hline Year & Land use & $\begin{array}{c}\text { Total } \\
\text { area (ha) }\end{array}$ & $\begin{array}{c}\% \text { of } \\
\text { total area }\end{array}$ & $\begin{array}{c}\text { Number } \\
\text { of } \\
\text { patches }\end{array}$ & $\begin{array}{c}\text { Total } \\
\text { length of } \\
\text { edge }(\mathbf{m})\end{array}$ & $\begin{array}{l}\text { Total } \\
\text { length of } \\
\text { edge } \\
(\mathbf{m} / \mathbf{h a})\end{array}$ & $\begin{array}{l}\text { Average } \\
\text { size (ha) }\end{array}$ & $\begin{array}{c}\text { Variation } \\
\text { in size of } \\
\text { patches }\end{array}$ \\
\hline 1938 & 1 , water body & 14.8 & 4.7 & 8 & 23,200 & 72.8 & 1.8 & 2.4 \\
\hline 1938 & $\begin{array}{l}2, \text { non-stocked } \\
\text { forest land }\end{array}$ & 53.6 & 16.8 & 20 & 22,858 & 71.7 & 2.7 & 4.2 \\
\hline 1938 & 3 , clear-cut area & 238.6 & 74.9 & 13 & 38,160 & 119.8 & 18.4 & 27.2 \\
\hline 1938 & $\begin{array}{l}\text { 4, young } \\
\text { plantation }\end{array}$ & 6.8 & 2.1 & 1 & 2,160 & 6.8 & 6.8 & 0 \\
\hline 1938 & $\begin{array}{l}5, \text { small pole } \\
\text { stage and pole- } \\
\text { stage stand }\end{array}$ & 5.0 & 1.5 & 1 & 1,506 & 4.7 & 4.9 & 0 \\
\hline 1953 & 1 , water body & 10.0 & 3.2 & 2 & 12,216 & 38.4 & 5.0 & 1.0 \\
\hline 1953 & $\begin{array}{l}\text { 2, non-stocked } \\
\text { forest land }\end{array}$ & 49.5 & 15.6 & 21 & 22,274 & 70.1 & 2.4 & 4.4 \\
\hline 1953 & 3 , clear-cut area & 196.5 & 61.8 & 13 & 33,900 & 106.7 & 15.1 & 27.9 \\
\hline 1953 & $\begin{array}{l}\text { 4, young } \\
\text { plantation }\end{array}$ & 19.5 & 6.1 & 6 & 6,158 & 19.4 & 3.2 & 1.7 \\
\hline 1953 & $\begin{array}{l}\text { 5, small pole } \\
\text { stage and pole- } \\
\text { stage stand }\end{array}$ & 40.9 & 12.9 & 4 & 11,414 & 35.9 & 10.2 & 8.6 \\
\hline 1953 & $\begin{array}{l}6, \text { high forest and } \\
\text { mature stand }\end{array}$ & 1.4 & 0.4 & 1 & 670 & 2.1 & 1.4 & 0 \\
\hline 1990 & 1 , water body & 9.2 & 2.8 & 2 & 12,368 & 38.2 & 4.6 & 0.6 \\
\hline 1990 & $\begin{array}{l}\text { 2, non-stocked } \\
\text { forest land }\end{array}$ & 38.8 & 12.0 & 28 & 21,468 & 66.4 & 1.4 & 2.6 \\
\hline 1990 & 3 , clear-cut area & 13.1 & 4.1 & 15 & 9,930 & 30.7 & 0.9 & 1.0 \\
\hline 1990 & $\begin{array}{l}\text { 4, young } \\
\text { plantation }\end{array}$ & 20.6 & 6.4 & 9 & 8,932 & 27.6 & 2.3 & 1.6 \\
\hline 1990 & $\begin{array}{l}5, \text { small pole } \\
\text { stage and pole- } \\
\text { stage stand }\end{array}$ & 40.8 & 12.6 & 10 & 14,514 & 44.9 & 4.1 & 4.7 \\
\hline 1990 & $\begin{array}{l}6, \text { high forest and } \\
\text { mature stand }\end{array}$ & 200.8 & 62.1 & 9 & 33,068 & 102.2 & 22.3 & 39.7 \\
\hline 2006 & 1, water body & 9.8 & 3.0 & 4 & 13,248 & 41.2 & 2.4 & 2.5 \\
\hline 2006 & $\begin{array}{l}2, \text { non-stocked } \\
\text { forest land }\end{array}$ & 26.2 & 8.2 & 18 & 14,160 & 44.1 & 1.5 & 2.8 \\
\hline 2006 & 3 , clear-cut area & 49.6 & 15.4 & 18 & 25,278 & 78.7 & 2.8 & 3.7 \\
\hline 2006 & $\begin{array}{c}\text { 4, young } \\
\text { plantation }\end{array}$ & 28.7 & 8.9 & 20 & 15,008 & 46.7 & 1.4 & 1.4 \\
\hline 2006 & $\begin{array}{l}5, \text { small pole } \\
\text { stage and pole- } \\
\text { stage stand }\end{array}$ & 27.5 & 8.6 & 6 & 8,142 & 25.3 & 4.6 & 6.6 \\
\hline 2006 & $\begin{array}{l}6, \text { high forest and } \\
\text { mature stand }\end{array}$ & 179.4 & 55.9 & 5 & 24,618 & 76.6 & 35.9 & 47.2 \\
\hline
\end{tabular}


The landscape heterogeneity index increased by $62 \%$ between the years 1938 and 2006, and the diversity indices show an upward trend for the same period (Table 2).

Table 2: The development of the landscape structure in the study area

\begin{tabular}{c|ccccccc} 
Year & $\begin{array}{c}\text { Shannon's } \\
\text { diversity } \\
\text { index }\end{array}$ & $\begin{array}{c}\text { Simpson's } \\
\text { diversity } \\
\text { index }\end{array}$ & $\begin{array}{c}\text { Shannon's } \\
\text { equitability } \\
\text { index }\end{array}$ & $\begin{array}{c}\text { Simpson's } \\
\text { equitability } \\
\text { index }\end{array}$ & $\begin{array}{c}\text { Index of } \\
\text { landscape } \\
\text { heterogeneity }\end{array}$ & $\begin{array}{c}\text { Total } \\
\text { area of } \\
\text { forest } \\
\text { (ha) }\end{array}$ & $\begin{array}{c}\text { Total } \\
\text { length of } \\
\text { edges } \\
\text { (m) }\end{array}$ \\
\hline $\mathbf{1 9 3 8}$ & 0.8 & 0.4 & 0.5 & 0.5 & 7.0 & 250.2 & 27,336 \\
$\mathbf{1 9 5 3}$ & 1.2 & 0.6 & 0.6 & 0.7 & 9.3 & 258.3 & 25,025 \\
$\mathbf{1 9 9 0}$ & 1.2 & 0.6 & 0.7 & 0.7 & 10.4 & 275.4 & 25,925 \\
$\mathbf{2 0 0 6}$ & 1.4 & 0.6 & 0.8 & 0.8 & 11.9 & 285.2 & 23,388
\end{tabular}

The trend in diversity changes in the landscape within the study area correlate in time with development of the ecological stability coefficients $\left(\mathrm{K}_{\mathrm{ES}}\right)$ calculated using two different methods (Table 3). The table clearly shows that all values for individual $\mathrm{K}_{\mathrm{ES}}$ within the study area gradually increase slightly over the period 1938 to 2006 . The $\mathrm{K}_{\mathrm{ES}}$ for all the years analysed according to Míchal (1985) indicates a balanced and highly stable ecological landscape. Similarly, the $\mathrm{K}_{\mathrm{ES}}$ values according to Miklós (1986) and Lipský (2000) indicate only a slightly disturbed and ecologically stable landscape over the same period. The degree of ecological stability of the forest stands remains constant over the whole study period with a maximum value of 5 (Table 3), which is in accordance with the development of the $\mathrm{K}_{\mathrm{ES}}$ values, as this value for degree of ecological stability (i.e. extraordinary significance) includes natural forests as floodplain forest in the study area (Buček and Lacina, 1996).

Table 3: Changes in the ecological stability of the study area

\begin{tabular}{c|cccc}
$\mathbf{Y}$ & $\begin{array}{c}\text { Landscape } \\
\text { stability index } \\
\mathbf{K}_{\mathrm{ES}}\end{array}$ & $\begin{array}{c}\text { Landscape } \\
\text { stability index } \mathbf{K}_{\mathrm{ES}} \\
\text { (Miklós, 1986 } \\
\text { and Lipský, 2000) }\end{array}$ & $\begin{array}{c}\text { Coefficient } \\
\text { of anthropogenic } \\
\text { impact } \\
\text { (Míchal, 1985) }\end{array}$ & $\begin{array}{c}\text { The degree } \\
\text { of ecological } \\
\text { stability } \\
\text { of the forest }\end{array}$ \\
\hline $\mathbf{1 9 3 8}$ & 5.53 & 0.73 & 12.78 & 5 \\
$\mathbf{1 9 5 3}$ & 5.78 & 0.79 & 12.53 & 5 \\
$\mathbf{1 9 9 0}$ & 6.89 & 0.81 & 13.01 & 5 \\
$\mathbf{2 0 0 6}$ & 6.89 & 0.81 & 13.07 & 5 \\
\hline
\end{tabular}

Over the course of 1938-2006, total fragmentation of the floodplain geobiocenosis in the Vrapač National Nature Reserve decreased slightly. The ecological stability of the area, 
however, has not decreased. In fact, it has increased very slightly. Evaluation of the values for the anthropogenic impact coefficient $\left(\mathrm{K}_{\mathrm{aov}}\right)$ indicates only a very weak anthropogenic impact on the geobiocenoses (Table 3).

\section{DISCUSSION}

Landscape heterogeneity is of great importance for the biotic value (Forman, 1995) and biodiversity of the landscape (Saunders et al., 1991). The results from this study area demonstrate that the development of the length of edges is similar to the index of landscape heterogeneity, in accordance with Newton (2007). When carrying out a landscapeecological analysis, however, it is necessary to understand that the values of $\mathrm{K}_{\mathrm{ES}}$ and $\mathrm{K}_{\mathrm{aov}}$ have an informative value only. The employment of anthropogenic evaluation of vegetation in the case of the Vrapač National Nature Reserve is slightly misleading, as the calculation of this coefficient reflects only those impacts on the vegetation that are direct and clearly visible while leaving aside indirect anthropogenic impacts (e.g. impacts on the hydrological condition which are very strong within the study area - see Machar, 2001a).

Míchal et al. (1992), in assessing the general trends related to forest ecosystem development in the Czech Republic in the $20^{\text {th }}$ century, produced the hypothesis that fragmentation of the floodplain forest geobiocenosis has increased over the course of the $20^{\text {th }}$ century, whereas the ecological stability of the landscape has decreased. This hypothesis was tested in this study, but was not proved. A surprising result of this study was that between 1938 and 2006 there was a gradual decrease in fragmentation within the study area and a slight increase in its ecological stability. In contrast with these results, the overall trend of landscape changes over the course of the $20^{\text {th }}$ century in the Czech Republic (Czech Statistical Office, 1999) is exactly the opposite, showing a considerable decrease in the structural heterogeneity of the landscape, and especially in the agricultural landscape (Lipský, 1995; Sklenička, 2002). Similarly, Kiliánová (2001) states that the ecological stability of the River Morava floodplain has decreased considerably over the course of the $20^{\text {th }}$ century. An explanation for the results presented may be found in the forestry management of the study area. Until 1872, the alluvial forests in the study area were managed as composite forest with a rotation period of 40 years and with seed trees mainly of oak and, occasionally, other species. Beginning in 1872, and increasingly during the first half of the $20^{\text {th }}$ century, the former production-type forest was intentionally converted to a high forest type. This was carried out by means of increasing the rotation period, which subsequently led to the increasing age of the forest stand. It is apparent, therefore, that the present richly structured floodplain forest stands within the Vrapač National Nature Reserve are the result of intensive forest management (Hošek, 1985). These findings, however, cannot be taken as the basis for more far-reaching conclusions related to landscape ecology because the study area is only a partial segment of a larger landscape that requires analysis at the basin scale (Peres and Terborgh, 1995). To conclude, intensive economic activity in the River Morava floodplain over the course of centuries has resulted in a conditional natural state of the floodplain forest geobiocenoses with unusually high biodiversity (Maděra, 2003; Maděra et al. 2008). These results are in accordance with Staus et al. (2002), who concluded that landscape dynamics in forests are strongly influenced by human decisions and land policy. 


\section{ACKNOWLEDGEMENTS}

This work was supported through a grant from the Czech Ministry of the Environment "Biodiversity and the target management of endangered species in the biotopes of the low and composite forests of the Natura 2000 system". I would like to thank Petr Zifčák for help with the data analysis in the GIS environment.

\section{REFERENCES}

Buček, A., Lacina, J. (1994). Biogeografické poměry. Aspects for revitalization of floodplain River Dyje near Nové Mlýny - confluence with River Morava. Institute of geoniche Academy of Science of the Czech Republic, Brno, pp 28 - 50.

Buček, A., Lacina J. (1996). An ecological network in the Czech Republic. Veronika, Brno, pp 45.

Culek, M. (1996). Biogeografické členěni České republiky. Enigma, Praha, pp 347.

Czech Statistical Office (1999). Statistická ročenka České republiky. Scientia, Praha, pp 712.

Fahrig, L. (2003). Effects of habitat fragmentation on biodiversity. Annual Review of Ecology, Evolution and Systematics, 34:.487-515.

Farina, A. (2007). Principles and Methods in Landscape Ecology. Springer, Dordrecht, pp 412.

Franklin, A.B., Noon, B.R. \& George, T.L. (2002). What is habitat fragmentation? Studies in Avian Biology, 25:20 - 29.

Forman, R.T.T. (1995). Land Mosaics : The Ecology of Landscape and Regions. Cambridge University Press, Cambridge, UK, pp 632.

Hošek, E. (1985). Historie lesů v CHKO Litovelské Pomoraví. Territorial Agency of Nature Conservation, Olomouc, pp 92.

Chytrý, M., Kučera, T. \& Kočí, M. (2001). Katalog biotopů České republiky. Agency of Nature Conservation Czech Republic, Praha, pp 304.

Kiliánová, H. (2001). Hodnocení změn lesních geobiocenóz v nivě reky Moravy v 19. století. PhD. thesis. Mendel University of Agriculture and Forestry, Brno, pp 116.

Lipský, Z. (1995). The changing face of the Czech rural landscape. Landscape and Urban Planning, 31:39-45.

Lipský, Z. (2000). Hodnocní změn kulturni krajiny. University textbook, Czech University of Agriculture, Praha, pp 71.

Löw, J. (1995). Rukovět' projektanta mistního územního sytému ekologické stability. Doplněk Publisher, Brno, pp 122.

Maděra, P. (2003). Změny geobiocenóz lužních lesů. Hab. Thesis, Mendel University of Agriculture and Forestry, Brno, pp 117.

Maděra, P., Vukelič, J., Buček, A. \& Baričevič, D. (2008). Floodplain forest plant communities. In: Klimo, E., Hager, H., Matić, S., Anić, I. \& Kulhavý, J. (Eds.), Floodplain forests of the temperate zone of Europe. pp 102-159. Lesnická práce, Kostelec nad Černými lesy,

Machar, I. (2001a). Krajinně ekologické hodnoceni lužních lesů v Litovelském Pomoraví. PhD. thesis. Mendel University of Agriculture and Forestry, Brno, pp 155. 
Machar, I. (2001b). Ekologický nivní fenomén. Collection from the conference - Face of the Earth - Landscape of home. Vol. 1. Czech chamber of architects, Praha, pp 135 - 137.

Míchal, I. (1985). Ekologický plán ČSR. Terplan, Praha, pp 97.

Míchal, I. (1994). Ecologická stabilita. Veronika and Ministry of the environment of the Czech Republic, Brno, pp 244.

Míchal, I., Buček, A., Hudec, K., Lacina, J., Macků, J. \& Šindelář, J. (1992). Obnova ekologické stability lesů. Academia, Praha, pp 169.

Miklós, L. (1986). Ekologická stabilita v Ekologickém plánu SSR. Životné prostredie, 20 (2):87 - 93 .

Mimra, M. (1993). Hodnoceni krajinné heterogeneity.. PhD thesis. Czech Univ. of Agric., Praha, 202 pp.

Montágová, E. (1999). Plán péče pro NPR Vrapač. Master thesis. Mendel University of Agriculture and Forestry Brno, pp 74.

Newton, A.C. (2007). Forest Ecology and Conservation. Oxford University Press, Oxford, pp 454.

Peres, C.A., Terborgh, J.W. (1995). Amazonian nature reserves : An analysis of the defensibility status of existing conservation units and design criteria for the future. Conservation Biology 9: 34-46.

Primack, R.B., Kindlmann, P. \& Jersáková, J. (2001). Biologické principy ochrany př́rody. Portál, Prague, pp 349.

Saunders, D.A., Hobbs, R.J. \& Margules, C.R. (1991). Biological consequences of ecosystem fragmentation : a review. Conservation Biology 5: 18-32.

Simon, J. (2007). Růstové modely v bohatě strukturovaných lesích. In: Vacek, S., Simon, J. \& Remeš, J. (Eds.): Management of diversification and natural forests. pp $147-188$. (Monograph). Forestry work, Kostelec nad Černými lesy,

Sklenička, P. (2002). Temporal changes in pattern of one agricultural Bohemian landscape during the period 1938 - 1998. Ekológia, Bratislava, 21 (2): 181 - 191.

Staus, N.L., Strittholt, J.R., DellaSala, D.A. \& Robinson, R. (2002). Rate and pattern of forest disturbance in the Klamat-Siskiyou ecoregion, USA, between 1972 and 1992. Landscape Ecology 17: 455-470.

Thomson, M.J. (2006): Forest Fragmentation. Ontario Nature. Retrieved 2007, January, from http://www.ontarionature.org/pdf/fragmentation.pdf.

Walker, S., Rogers, G.M., Lee, W.G., Rance, B., Ward, D. Rufaut, C. Conn, A., Simpson, N., Hall, G. \& Larivi, R.M.C. (2006). Consequences to threatened plans and insects of fragmentation of Southland floodplain forests. Science for Conservation 265. Retrieved 2007, January, from http://www.doc.govt.nz/upload/documents/science_and_technical. sfc265.pdf. 

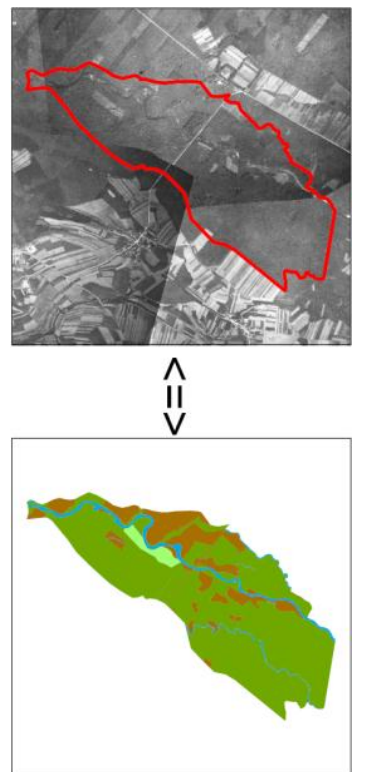

1938
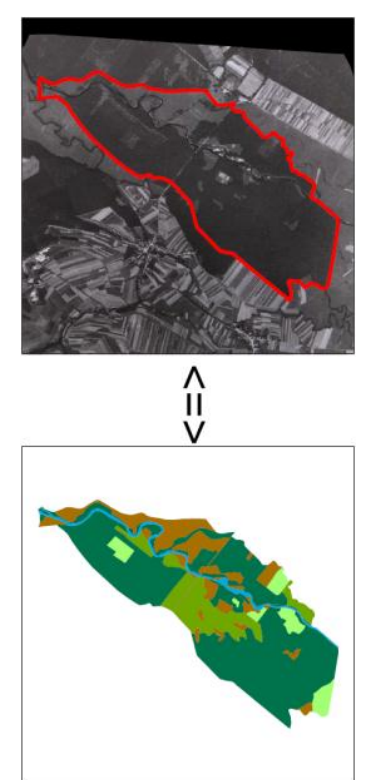

1953

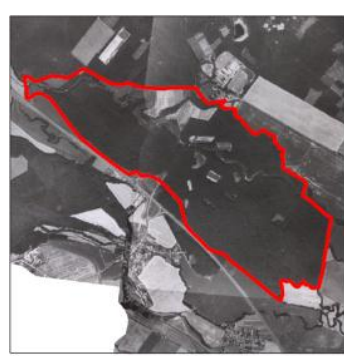

॥I

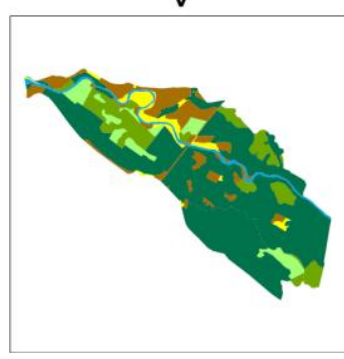

1990

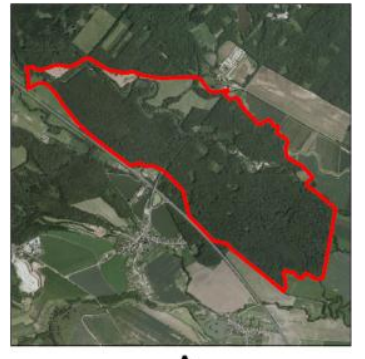

II

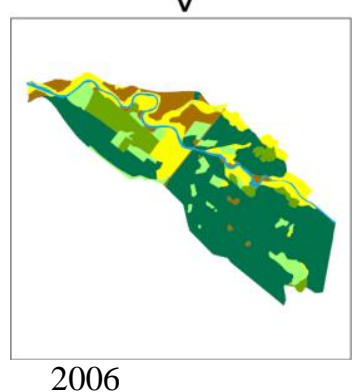

2006

Fig. 3: The development of landscape coverage within the study area according to the six land-use categories

\begin{tabular}{|l|l|}
$\begin{array}{l}\text { Water } \\
\text { body }\end{array}$ & Clear-cut \\
area \\
$\begin{array}{l}\text { Non- } \\
\text { stocked } \\
\text { forest land }\end{array}$ & Young \\
\hline
\end{tabular}

